Bangladesh J. Zool. 49 (2): 229-241, 2021

ISSN: 0304-9027

eISSN: $2408-8455$

\title{
MORPHOMETRY OF RHINOMUGIL CORSULA (HAMILTON, 1822) FROM SITAKUNDA COAST OF THE BAY OF BENGAL, BANGLADESH
}

\author{
Syeda Ismat Ara, Mohammad Ali Azadi*1, Munira Nasiruddin and Aftab Hossain \\ Department of Zoology, University of Chittagong, Chattagram 4331, Bangladesh
}

\begin{abstract}
A total of 65 specimens of Rhinomugil corsula (Hamilton, 1822), measuring from $8.1 \mathrm{~cm}$ to $28.9 \mathrm{~cm}$ in total length, collected from the Sitakunda coast of the Bay of Bengal, were used for the morphometric analysis during the period between March 2016 and February 2018. Twenty seven morphometric characters were selected and studied during the investigation period. The regression equations - both arithmetic and logarithmic - between the total length (TL) and 21 morphometric characters, and head length (HL) with five morphometric characters related to the head, were determined. The value of coefficient of correlation ' $r$ ' for each relationship was calculated and t-test for each ' $r$ ' value was also done. The relationships of the various measurements of the body with the total length - and head length with the five relevant characters -of $R$. corsula from the Sitakunda coast of the Bay of Bengal showed linear relationships, which were highly significant $(\mathrm{P}<0.01)$. The ranges of ' $\mathrm{b}$ ' values 0.967 to 1.346 in case of the relationships between TL and 21 relevant characters, whereas 0.906 to 1.236 in case of the relationships between HL and 5 relevant characters. These values differ insignificantly $(P>0.01)$ with typical value $b=1$ indicating isometric relationships among the characters.
\end{abstract}

Key words: Morphometric analysis, Rhinomugil corsula, Sitakunda coast.

\section{INTRODUCTION}

Morphometric characters are measurements of different measurable characters of body parts of an organism (Talwar and Jhingran 1991). Information on morphometric measurements and statistical relationship among them are widely used in fish taxonomy (Lagler 1956). Among different tools used in fish identification, morphological characters - also called morphological systematics (Nayman 1965) - are very much essential (Fatima 1991) as it has for sometimes been used as an important tool for defining or characterizing fish stock unit in ichthyology (Tudela 1999). Morphometric differences among stocks of a species are considered as very crucial for evaluating the population structures and identifying different fish races and populations of the same species (Turan 2004,

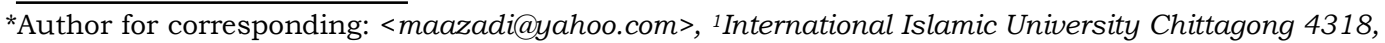
Bangladesh

@2021 Zoological Society of Bangladesh DOI: https://doi.org/10.3329/bjz.v49i2.56260 
Turan et al. 2004, Vishalakshi and Singh 2008). Morphometrics can be used to quantify a trail of evolutionary significance, and by detecting changes in the shape, assuming their ontogeny, function or evolutionary relationship (Ambily 2016). Studies on morphometric characters might have potential value in taxonomy and conservation and fisheries management (Motomura et al. 2005, Quist et al. 2009), and also is very important from various view point including evolution ecology, behavior, conservation, management of water resources and stock assessment (Anvarifar et al. 2011). Separation of stocks or races of commercially important fishes is of great importance in fishery investigations (Witthames et al. 1995); as slight but significant changes occur in the morphometric measurements between the fishes of different stocks, races or populations.

Rhinomugil corsula (Mugillidae: Perciformes) - found in the rivers and estuaries of southern Asia, in Bangladesh, India, Nepal and Myanmar (Froese and Pauly 2018) - is very hardy fish, and can tolerate a wide range of salinity and temperature (Riede 2004, Ara et al. 2019), hence, could be a good candidate for morphological changes within its local populations of rivers and coastal areas. Hence, this species was selected for morphometric study.

Numerous studies have been conducted on the aspect of morphometric characters of different fishes by different researchers. Some notable ones are: Pillay (1957), Royce (1963), Chondar (1977), Prakash and Varma (1982), Hoque (1984), Johal et al. (1989), Azadi et al. (1990), Azadi and Naser (1996), Corti and Crosetti (1996), Austin (1999), Ismen (2001), Motomura et al. (2005), Azadi and Rahman (2008), Quist et al. (2009), Narejo (2010), Dars et al. (2012) and Nath and Kunda (2017).

Works have also been done on morphometric studies of different mullets such as Ibanez-Aguirre et al. (2006) on Mugil curema; Kohestan-Eskandari et al. (2006) on Liza aurata; Renjini and Nandan (2011) on Liza parsia; Razzaq et al. (2015) on Mugil incilis and Zubia et al. (2015) on Liza melinoptera, L. Macrolepis, Mugil cephalus and Valamugil speigleri. Sultana et al. (2013) gave a mere mention of some of the morphometric characters of freshwater specimens of $R$. corsula from southern-western coastal rivers of Khulna Division of Bangladesh. In the present investigation, morphometric measurements and growth rate of different body parts in relation to total length and head length of fish were studied from the Sitakunda coast of the Bay of Bengal, which is subjected to environmental pollution from different industries in the last few decades.

\section{MATERIAL AND METHODS}

A total of 65 Rhinomugil corsula (Hamilton, 1882), measuring from 8.1 to $28.9 \mathrm{~cm}$ in length, were collected from the fishermen's catch of the Sitakunda 
coast of the Bay of Bengal between March 2016 and February 2018 for morhpometric analysis. After collection, the specimens were transported to the Limnology and Fisheries Laboratory of the Department of Zoology, University of Chittagong with ice to avoid decomposition and then various measurements were taken, as soon as possible, using divider and measuring board having graduations in $\mathrm{cm}$. Eye diameter and inter orbital distance were measured by slide callilpers $(0.1 \mathrm{~cm})$. Twenty seven morphometric characters were studied following the standard procedures described in Day (1889), Holden and Raitt (1974), and Joyaram (1981).

The following twenty seven morphometric characters were measured and investigated for each fish: Total Length (TL), Standard Length (SL), Fork Length (FL), Head Length (HL), Pre-Dorsal length (PDL), Length of the first dorsal fin $\left(\mathrm{L} 1^{\text {st }} \mathrm{DF}\right)$, Base length of the first dorsal fin (BL1 $\left.1^{\text {st }} \mathrm{DF}\right)$, Length of the Second dorsal fin (L2 $\left.{ }^{\text {nd }} \mathrm{DF}\right)$, Base length of the Second dorsal fin (L2 $\left.{ }^{\text {nd }} \mathrm{DF}\right)$, Distance between first dorsal fin and second dorsal fin $\left(\mathrm{DDF}_{1} \& \mathrm{DF}_{2}\right)$, Length of pectoral fin (PecFL), Length of pelvic fin (PelFL), Distance between pectoral and pelvic fins (DPec\&Pel), Anal fin Length (AFL), Base of Anal fin (BAF), Distance between pelvic and anal fin (DPel\&Anal), Pre-anal fin length (PreAFL), Caudal fin length (CFL), Caudal peduncle Length (CPL), Maximum body width (MaxBW), Minimum body width (MinBW), Length of mouth cleft (MCL), Head Depth (HD), Eye diameter (ED), Pre-orbital distance (PreOD), Post orbital distance (PoOD), and Inter orbital distance (IOD).

The total length of each specimen was used as the basis of reference for all other measurements (Carlandar and Smith 1945, Hile 1948). The regression of various body characters of different specimens against total length were compared by using the covariance technique (Mather 1964). For computing the growth of body parts in relation to total length of the fish, the rectilinear regression was used, because the use of regression of original measurements rather than ratios is time saving, easier to interpret and less likely to lead to confusing or doubtful conclusions as stated by Marr (1955). In the present study, linear regression of various body proportions against total length was fitted by the least square method after logarithmic transformation. The regression equation is represented as:

$$
\log \mathrm{Y}=\mathrm{a}+\mathrm{bLog} \mathrm{X}
$$

Where, $\log \mathrm{Y}=$ Length of body parts of the fish (dependent variables),

$\log X=$ Total length of fish (or head length of fish for four variables), $\mathrm{a}=$ intercept, and

$b=$ regression coefficient or slope . 
In order to assess closeness of relationship, that might exist in different cases, correlation coefficient $(r)$ for all the morphometric characters were also computed and tested by t-test.

The rate of growth of different variables was estimated on the percentage basis using the following formula:

$$
\text { Growth rate }=\frac{\mathrm{Y}}{\mathrm{X}} \mathrm{X} 100 \%
$$

Where, ' $\mathrm{Y}$ ' is the observed value of the variable and ' $\mathrm{X}$ ' is the total length.

\section{RESULTS AND DISCUSSION}

A total of 65 specimens of Rhinomugil corsula (Hamilton, 1822), measuring from $8.1 \mathrm{~cm}$ to $28.9 \mathrm{~cm}$ in length, collected from the Sitakunda coast of the Bay of Bengal, were used in morphometric study for two years period between March 2016 and February 2018. Twenty seven morphometric characters were studied during the study period. The arithmetic and logarithmic form of equations between the total length (TL) and 21 morphometric characters, and head length (HL) with five morphometric characters related to the head, were determined and presented in Table 1.

The value of coefficient of correlation ' $r$ ' for each relationship was calculated and t-test for each ' $r$ ' value was also done (Table 2). The regression coefficient 'b' values for various morphometric characters studied are given in Table 2.

The relationships of the 21 various measurements of the body with the total length - and head length with the five relevant characters - of $R$. corsula showed linear relationships (Table1, Figs. 1 - 5). The significant correlation coefficient $(\mathrm{r})$ was found for all the studied characters (Table 2).

Range, mean, proportion, regression coefficient (b), correlation coefficient $(r)$ and $\mathrm{t}$-value of morphometric characters (dependent variables) of $R$. corsula are presented in Table 2. When total length was compared to different morphometric characters other than those related to head, the range of 'b' value varied from 0.967 to 1.346 . Among them, five were smaller than 1.0 and the remaining sixteen were greater than 1.0 (Table 2). On the other hand, for the five characters (related to head) compared with head length the range of 'b' value was from 0.907 to 1.236 . One of them was smaller than 1.0 and four were greater than 1.0 (Table 2). The top five morphometric characters which had greater growth rate, according to 'b' value, were base length of first dorsal fin (1.346), maximum body width (1.329), mouth cleft length (1.237), distance between first dorsal fin and second dorsal fin (1.234), and distance between pelvic fin and anal fin (1.243) (Table 2). And the lowest five morphometric characters which had the lower growth rate were - post orbital 
distance (0.907), pelvic fin length (0.967), anal fin length (0.972), head length (0.976) and pre-dorsal distance (0.995) (Table 2).

Table 1 Arithmetic and logarithmic form of equations of different relationships between total length. and other 21 morphometric characters, and head length and other related morphometric characters of $R$. corsula from Sitakunda coast of the Bay of Bengal

\begin{tabular}{|c|c|c|}
\hline \multirow{2}{*}{ Relationship } & \multicolumn{2}{|c|}{ Regression equation } \\
\hline & Arithmetic (W=aTL $)$ & Logarithmic $(Y=a+b x)$ \\
\hline TL vs SL & $\mathrm{SL}=0.8203 \mathrm{TL}^{1.003}$ & $\mathrm{SL}=-0.08+1.003 \mathrm{TL}$ \\
\hline TL vs FL & $\mathrm{FL}=0.9732 \mathrm{TL}^{0.996}$ & $\mathrm{FL}=-0.012+0.996 \mathrm{TL}$ \\
\hline TL vs HL & $\mathrm{HL}=0.2128 \mathrm{TL}^{0.976}$ & $\mathrm{HL}=-0.672+0.976 \mathrm{TL}$ \\
\hline TL vsPreDD & PreDD $=0.4361 \mathrm{TL}^{0.995}$ & PreDD $=-0.36+0.995 \mathrm{TL}$ \\
\hline TL vs L $1^{\text {st }} \mathrm{DF}$ & $\mathrm{L} 1^{\text {st }} \mathrm{DF}=0.0526 \mathrm{TL}^{1.182}$ & $\mathrm{~L} 1^{\mathrm{st}} \mathrm{DF}=-1.28+1.182 \mathrm{TL}$ \\
\hline TL vs BL1 $1^{\text {st }} \mathrm{DF}$ & $\mathrm{BL} 1^{\mathrm{st}} \mathrm{DF}=0.0217 \mathrm{TL}^{1.346}$ & $B L 1{ }^{\text {st }} \mathrm{D}=-1.66+1.346 \mathrm{TL}$ \\
\hline TL vs L2 ${ }^{\text {nd }} \mathrm{DF}$ & $\mathrm{L} 2^{\text {nd }} \mathrm{DF}=0.1012 \mathrm{TL}^{1.056}$ & $\mathrm{~L} 2^{\text {nd }} \mathrm{DF}=-0.995+1.056 \mathrm{TL}$ \\
\hline TL vs BL2 $2^{\text {nd }} \mathrm{DF}$ & $B L 2^{\text {nd }} \mathrm{DF}=0.0564 \mathrm{TL}^{1.06}$ & $\mathrm{BL} 2^{\text {nd }} \mathrm{DF}=-1.248+1.06 \mathrm{TL}$ \\
\hline TL vs $\mathrm{DDF}_{1} \& \mathrm{DF}_{2}$ & $\mathrm{DDF}_{1} \& \mathrm{DF}_{2}=0.074 \mathrm{TL}^{1.235}$ & $\mathrm{DDF}_{1} \& \mathrm{DF}_{2}=-1.13+1.235 \mathrm{TL}$ \\
\hline TL vsPecFL & PecFL $=0.1405 T^{1.07}$ & PecFL $=-0.0852+1.07 \mathrm{TL}$ \\
\hline TL vsPelFL & PelFL $=0.1281 \mathrm{TL}^{0.967}$ & PelFL $=-0.892+0.967 \mathrm{TL}$ \\
\hline TLvsDPecF\&PelF & $\mathrm{DPecF} \& \mathrm{PelF}=0.0703 \mathrm{TL}^{1.125}$ & $\mathrm{DPecF} \& \mathrm{PelF}=-1.153+1.125 \mathrm{TL}$ \\
\hline TL vs AFL & $\mathrm{AFL}=0.1339 \mathrm{TL}^{0.972}$ & $\mathrm{AFL}=-0.873+0.972 \mathrm{TL}$ \\
\hline TL vs BLAF & $\mathrm{BLAF}=0.0546 \mathrm{TL}^{1.17}$ & $\mathrm{BLAF}=-1.263+1.17 \mathrm{TL}$ \\
\hline TL vsDPelF\&AF & DPelF\&AF $=0.1140 \mathrm{TL}^{1.243}$ & $\mathrm{DPelF} \& \mathrm{AF}=-0.943+1.243 \mathrm{TL}$ \\
\hline TL vsPreAL & PreAL $=0.3818 T^{1} L^{1.129}$ & PreAL $=-0.418+1.129 \mathrm{TL}$ \\
\hline TL vs CFL & $\mathrm{CFL}=0.13 \mathrm{TL}^{1.138}$ & $\mathrm{CFL}=-0.886+1.138 \mathrm{TL}$ \\
\hline TL vs CPL & $\mathrm{CPL}=0.1049 \mathrm{TL}^{1.16}$ & $\mathrm{CPL}=-0.979+1.16 \mathrm{TL}$ \\
\hline TL vsMaxBD & $\operatorname{MaxBD}=0.0606 \mathrm{TL}^{1.33}$ & $\operatorname{MaxBD}=-1.216+1.33 \mathrm{TL}$ \\
\hline TL vs Min BD & $\operatorname{MinBD}=0.0618 \mathrm{TL}^{1.116}$ & $\operatorname{MinBD}=-1.202+1.116 \mathrm{TL}$ \\
\hline TL vs MCL & $\mathrm{MCL}=0.0283 \mathrm{TL}^{1.237}$ & $\mathrm{MCL}=-1.552+1.237 \mathrm{TL}$ \\
\hline HL vs HD & $\mathrm{HD}=0.5030 \mathrm{HL}^{1.049}$ & $\mathrm{HD}=-0.2983+1.049 \mathrm{HL}$ \\
\hline HL vs ED & $\mathrm{ED}=0.1358 \mathrm{HL}^{1.184}$ & $\mathrm{ED}=-0.867+1.184 \mathrm{HL}$ \\
\hline HL vsPreOD & $\operatorname{PreOD}=0.1369 \mathrm{HL}^{1.203}$ & PreOD $=-0.863+1.203 \mathrm{HL}$ \\
\hline HL vsPostOD & PostOD $=0.7321 \mathrm{HL}^{0.907}$ & PostOD $=-0.135+0.907 \mathrm{HL}$ \\
\hline HL vs IOD & $\mathrm{IOD}=0.1503 \mathrm{HL}^{1.24}$ & $\mathrm{IOD}=-0.823+1.24 \mathrm{HL}$ \\
\hline
\end{tabular}

As in the present study (Figs. 1 to 5), the linear relationship of various morphometric characters and the total length have also been reported by various authors such as Prakash and Varma (1982), Hoque and Rahman (1985), Azadi et al. (1990), Fatima (1991), Azadi and Naser (1996), Azadi and Rahman (2008), Dars et al. (2012). The linear relationship indicated that with the increase in total length, there was corresponding increase in the length of the body measurements of the studied fish. The relationships between the dependent variables and independent variables were also highly correlated and significant $(\mathrm{P}<0.01)$ for all cases (Table 2$)$. High correlation in various body measurements of various fishes were also observed by Bhuyian and Biswas (1982), Dasgupta (1991), Fatima (1991), Tandon et al. (1993), Renjini and Nandan (2011) and Zubia et al. (2015). Researchers often used the standard length (SL) of fishes in the research of morphometry of different fishes. Sarojini 
(1958) had used standard length of the Mugil cunnesius as the standard linear measurement instead of the total length, as the caudal fins were found damaged in most of the fish. Pillai (1983) made the biometry analysis in relation to standard length for Otolithes ruber. In the present study, total length was used as the standard linear measurement. Total length is more readily accepted and understood by everyone. Moreover, Pillay (1954) got some confusion in measuring standard length, as the base of the caudal fin in mullets is covered by scales and the end of the lateral line or the tip of the hypurals cannot be located easily. Ambily (2016) reported that morphometric variables can be separated into three categories, i.e., positive allometry $(+\mathrm{A})$, negative allometry $(-\mathrm{A})$ and isometry $(\mathrm{I})$. In positive allometry, the slope (allometry coefficient) is significantly greater than one $(>1.0)$ and the proportional variable increased relative to total length (TL). In negative allometry, the slope is significantly less than one $(<1)$ and the proportional variable decreased compared to TL. In isometry, the slope

Table 2. Range, mean, proportion, regression coefficient (b), correlation coefficient (r) and $t$ value of different morphometric characters (dependent variables) of $R$. corsula from Sitakunda coast of the Bay of Bengal

\begin{tabular}{llllllll}
\hline $\begin{array}{c}\text { Measurements } \\
\text { compared } \\
\text { to TL }\end{array}$ & Range & Mean \pm SD & $\begin{array}{c}\text { Proportion } \\
\text { (\%) }\end{array}$ & 'b' & r & t & $\begin{array}{c}\text { Signifi } \\
\text { cance }\end{array}$ \\
\hline SL & $7.0-24.0$ & $14.08 \pm 4.39$ & $82.73 \pm 2.22$ & 1.003 & 0.996 & 88.75 & $\mathrm{P}<0.01$ \\
FL & $7.9-27.9$ & $16.39 \pm 5.06$ & $96.37 \pm 1.26$ & 0.996 & 0.999 & 180.89 & $\mathrm{P}<0.01$ \\
HL & $1.45-5.5$ & $3.37 \pm 0.99$ & $19.33 \pm 0.96$ & 0.976 & 0.990 & 54.44 & $\mathrm{P}<0.01$ \\
PreDD & $3.4-12.0$ & $7.31 \pm 2.29$ & $43.0 \pm 1.42$ & 0.995 & 0.992 & 61.71 & $\mathrm{P}<0.01$ \\
L1st DF & $0.6-2.7$ & $1.51 \pm 0.55$ & $8.75 \pm 1.25$ & 1.182 & 0.993 & 66.53 & $\mathrm{P}<0.01$ \\
BL1 ${ }^{\text {st }}$ DF & $0.4-2.0$ & $1.02 \pm 0.44$ & $5.77 \pm 0.99$ & 1.346 & 0.950 & 24.10 & $\mathrm{P}<0.01$ \\
L2nd DF & $0.9-3.6$ & $2.02 \pm 0.67$ & $11.86 \pm 0.77$ & 1.056 & 0.978 & 36.92 & $\mathrm{P}<0.01$ \\
BL2nd DF & $0.5-2.0$ & $1.14 \pm 0.37$ & $6.69 \pm 0.61$ & 1.059 & 0.961 & 27.49 & $\mathrm{P}<0.01$ \\
DDF \&DF 2 & $0.9-4.5$ & $2.4 \pm 0.92$ & $14.28 \pm 1.10$ & 1.234 & 0.999 & 165.97 & $\mathrm{P}<0.01$ \\
PecFL & $1.4-5.1$ & $2.97 \pm 0.98$ & $17.32 \pm 0.82$ & 1.074 & 0.994 & 73.88 & $\mathrm{P}<0.01$ \\
PelFL & $0.9-3.2$ & $1.99 \pm 0.58$ & $11.73 \pm 0.82$ & 0.967 & 0.976 & 35.49 & $\mathrm{P}<0.01$ \\
DPecF\&PelF & $0.7-2.8$ & $1.72 \pm 0.60$ & $9.99 \pm 0.79$ & 1.125 & 0.979 & 38.06 & $\mathrm{P}<0.01$ \\
AFL & $0.9-3.8$ & $2.11 \pm 0.63$ & $12.45 \pm 1.06$ & 0.972 & 0.960 & 27.16 & $\mathrm{P}<0.01$ \\
BLAF & $0.4-2.7$ & $1.5 \pm 0.52$ & $8.76 \pm 1.29$ & 1.17 & 0.927 & 19.56 & $\mathrm{P}<0.01$ \\
DPelF\&AF & $1.6-7.5$ & $3.92 \pm 1.46$ & $22.54 \pm 2.10$ & 1.243 & 0.990 & 56.19 & $\mathrm{P}<0.01$ \\
PreAL & $4.0-17.0$ & $9.43 \pm 3.21$ & $58.82 \pm 3.27$ & 1.129 & 0.994 & 73.85 & $\mathrm{P}<0.01$ \\
CFL & $1.2-5.0$ & $3.3 \pm 1.05$ & $19.25 \pm 2.21$ & 1.138 & 0.964 & 28.80 & $\mathrm{P}<0.01$ \\
CPL & $1.0-4.9$ & $2.83 \pm 0.98$ & $16.44 \pm 1.34$ & 1.16 & 0.985 & 44.61 & $\mathrm{P}<0.01$ \\
MaxBD & $1.1-5.0$ & $2.68 \pm 1.04$ & $15.31 \pm 1.99$ & 1.329 & 0.981 & 39.79 & $\mathrm{P}<0.01$ \\
Min BD & $0.6-2.5$ & $1.47 \pm 0.50$ & $8.86 \pm 0.67$ & 1.116 & 0.981 & 40.32 & $\mathrm{P}<0.01$ \\
MCL & $0.2-1.5$ & $0.95 \pm 0.31$ & $5.52 \pm 0.98$ & 1.237 & 0.921 & 18.79 & $\mathrm{P}<0.01$ \\
HD* & $0.8-3.0$ & $1.81 \pm 0.58$ & $53.52 \pm 5.56$ & 1.048 & 0.955 & 25.46 & $\mathrm{P}<0.01$ \\
ED* & $0.2-1.0$ & $0.58 \pm 0.20$ & $16.99 \pm 2.15$ & 1.184 & 0.962 & 27.88 & $\mathrm{P}<0.01$ \\
PreOD* & $0.25-1.1$ & $0.6 \pm 0.22$ & $17.55 \pm 2.41$ & 1.204 & 0.952 & 24.80 & $\mathrm{P}<0.01$ \\
PostOD* & $1.0-3.4$ & $2.2 \pm 0.60$ & $65.77 \pm 0.32$ & 0.907 & 0.982 & 41.61 & $\mathrm{P}<0.01$ \\
IOD* & $0.3-1.3$ & $0.69 \pm 0.27$ & $19.99 \pm 2.59$ & 1.237 & 0.967 & 30.04 & $\mathrm{P}<0.01$ \\
\hline
\end{tabular}

* Characters compared with head length (HL) 


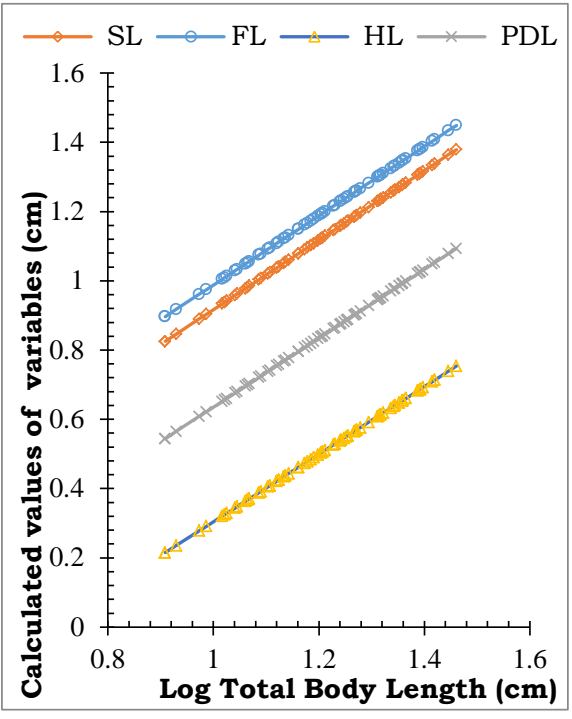

Fig. 1 Relationship of Total body length (TL) with Standard length (SL), Fork length (FL), Head length (HL) and Post dorsal length (PDL).

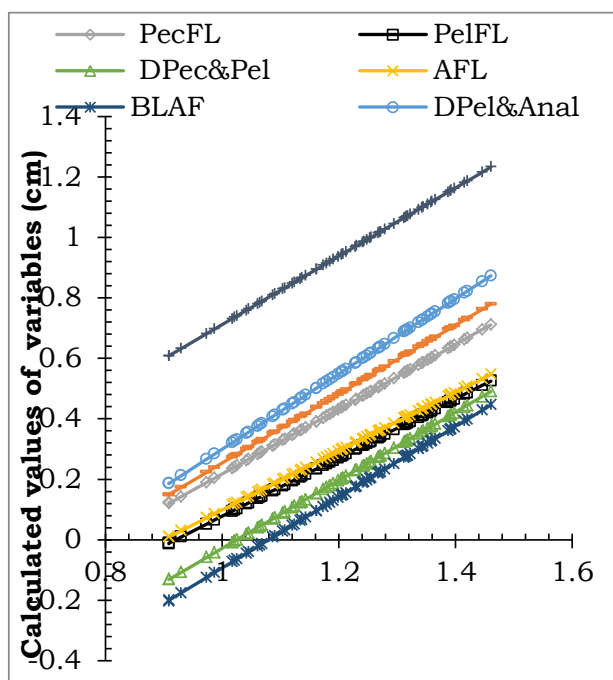

Log Total Body Length $(\mathrm{cm})$

Fig. 3 Relationship of Total body length (TL) with Pectoral fin length (PecFL), Pelvic fin length (PelFL), Distance between pectoral and pelvic fin (DPec\&Pel), Anal fin length (AFL), Base length of anal fin (BAF), Distance between pelvic and anal fin (DPel\& Anal), Preanal fin length (PreAFL) and Caudal fin length (CFL).

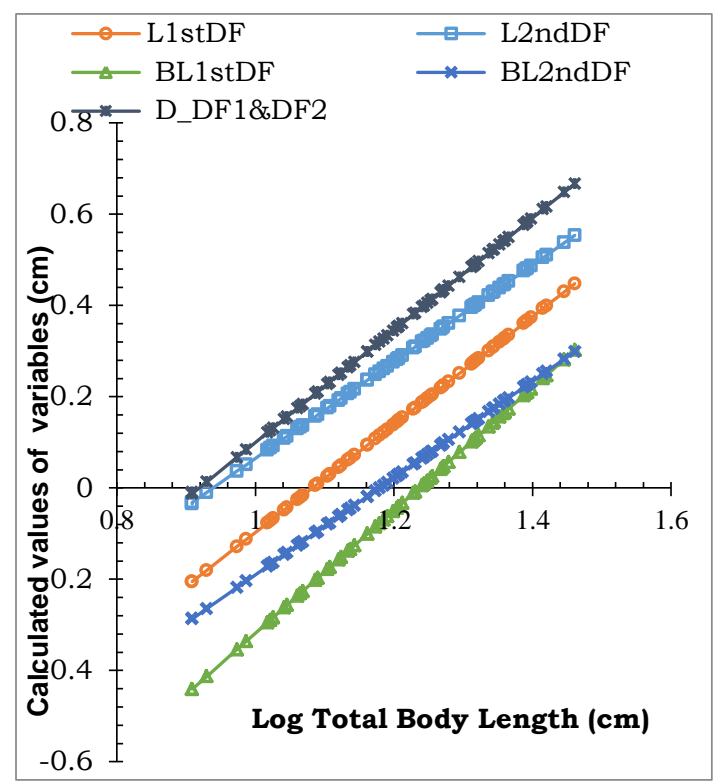

Fig. 2 Relationship of Total body length (TL) with Length of $1^{\text {st }}$ dorsal fin (L1 $\left.1^{\text {st }} \mathrm{DF}\right)$, Length of $2^{\text {nd }}$ dorsal fin (L2 $\left.{ }^{\text {nd }} \mathrm{DF}\right)$, Base length of $1^{\text {st }}$ dorsal fin $\left(B L 1^{\text {st } D F}\right)$, Base length of $2^{\text {nd }}$ dorsal fin $\left(B L 2^{\text {nd }} D F\right)$ and Distance between $1^{\text {st }}$ and $2^{\text {nd }}$ dorsal fin $\left(D_{-} \mathrm{DF}_{1} \& \mathrm{DF}_{2}\right)$.

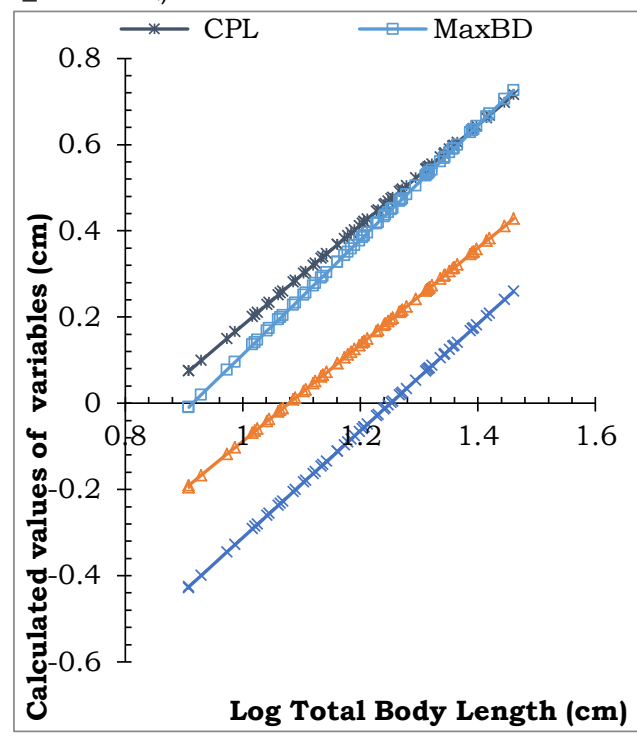

Fig. 4 Relationship of Total body length (TL) with Caudal peduncle length (CPL), Maximum body depth (MaxBD), Minimum body depth (MinBD) and Mouth cleft length (MCL). 


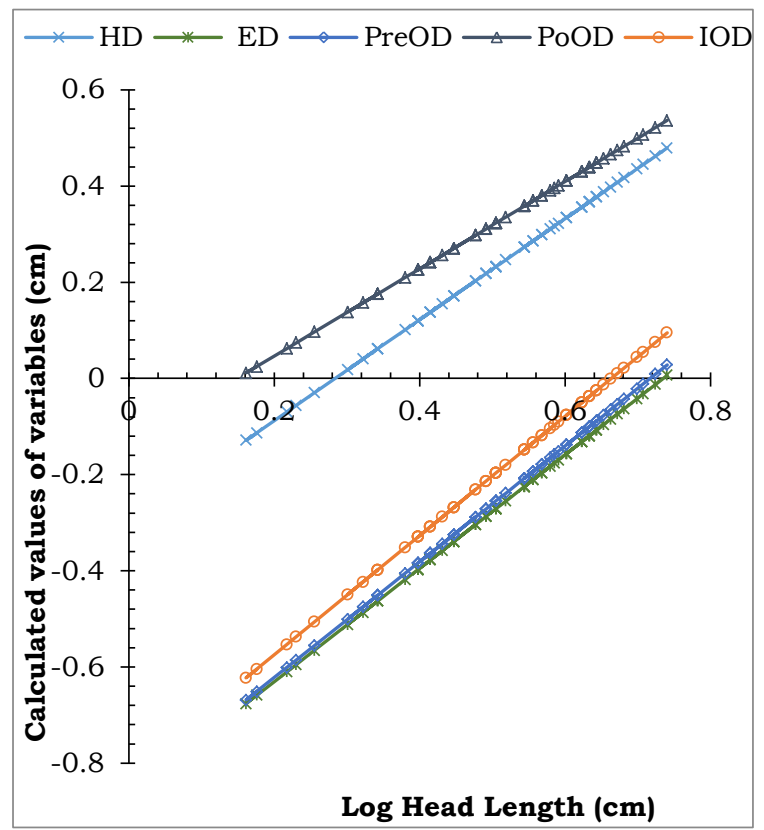

Fig. 5 Relationship of Head length (HL) with Head depth (HD), Eye diameter (ED), Preorbital distance (PreOD) and Intra orbital distance (IOD).

shows a non-significant difference from one (1) indicating direct proportionality among the variable and the total length. In the present study 'b' values for all morphometric characters are very close to 1.0 (Table2) and according to t-test there was no significant difference from $1.0(t=5.184$, $d f=25, P<0.01)$. This indicated isometric growth for all morphometric characters under consideration. Fatima (1991) and Ranganathan and Nataranjan (1969) also found isometric growth among morphometric characters of $R$. corsula from Yamuna River and two reservoirs of Tamil Nadu of India, respectively. However, some workers have reported that the regression of one character on the other showed a non-linear relationship (Godsil 1948, Marr 1955).

In the present study, higher growth rate was found in base length of first dorsal fin (1.346), maximum body width (1.329), mouth cleft length (1.237), distance between pelvic fin and anal fin (1.243) and $1^{\text {st }}$ and $2^{\text {nd }}$ dorsal fin (1.234) (Table 2). Fatima (1991) reported gut length (1.703), length of caudal peduncle (1.274), depth of body (1.207), width of head (1.161) and pre-dorsal length (1.082) to be the top five morphometric characters with faster growth rate for $R$. corsula in Yamuna Rive of India. The lowest growth rate was found in case of post-orbital distance (0.907) (Table 2) in the present study, but Fatima (1991) found standard length $(0.997)$ to have the lowest growth rate. 
Sultana et al. (2013) studied some morphometric characters of $R$. corsula from some rivers of the south-eastern part of Bangladesh and found many of the morphometric measurement higher than that of the present study. The adjustment of fish to the environmental condition by different adaptation to improve their suitability (Nacua et al. 2010), may exhibit differences in their morphometric characters (Jaiswar et al. 2004). Sitakunda coast is subjected to environmental pollution for decades (Hossain et al. 2016), the environmental changes in the habitat of the fish due to pollution are expected to cause morphological changes within species (Kaur et al. 2019). Hence, the variations in the morphometric characters might be due to different hormonal activity caused by environmental changes of the fish habitat as well as due to different genetic make-up (Ara 2020).

\section{LITERATURE CITED}

AMBILY, V. 2016. Phylogeny and life history traits of Arius subrostratus (Valenciennes, 1840) from Chochin estuary, India. Ph.D. thesis, Department of Zoology, NSS Hindu College, Changanacherry, affiliated to Mahatma Gandhi University, Kottayam, pp. 311.

ANVARIFAR, H., KHYABANI, A., FARAHMAND, H., VATANDOUST, S., ANVARIFAR, H. and JAHAGEERDAR, S. 2011. Detection of morphometric differentiation between isolated up- and downstream populations of Siah Mahi (Capoetacapoeta gracilis) (Pisces: Cyprinidae) in the Tajan River (Iran). Hydrobiologia 673:41-52.

ARA, S.I. 2020. Fishery and water quality of Sitakunda coast of the Bay of Bengal with reference to biology of Rhinomugil corsula (Hamilton 1822).PhD thesis, Department of Zoology, University of Chittagong, Chittagong, pp. 339.

ARA, S.I., AZADI, M.A., NASIRUDDIN, M., HOSSAIN, A. and MUSTAFA, M.G. 2019. Population dynamics of Mullet fish, Rhinomugil corsula (Hamilton 1822) in the Sitakunda coast of the Bay of Bengal. Bangladesh J. Zool. 47(2): 305-314.

AUSTIN, M. 1999. Morphometric separation of annual cohorts within mid- Atlantic bluefish, Pomatomus saltatrix, using discriminant function analysis. Fish. Bull. 97(3): 411-420.

AZADI, M.A. and NASER, A. 1996. Morphometry of Labeo bata (Ham.) from Kaptai reservoir, Bangladesh. Chittagong Univ. Stud. Part 2.Sci. 20(2):19-25.

AZADI, M.A. and RAHMAN, A.S.M.S. 2008. Morphometric and meristic study of Gudusia chapra (Hamilton, 1822) and Goniolosa manmania (Hamilton, 1822) (Clupeidae) from the Kaptai Lake, Bangladesh. Chittagong Univ. J. Biol. Sci. 3(1\&2): 21-31.

AZADI, M.A., ISLAM, M.A. and GOPAL, J. 1990. Relationship between body measurements and some internal organs in of the catfish, Mystus aor (Ham.), J. Asiat. Soc. Bangaldesh Sci. 16(1): 5-9.

BHUIAN, A.S. and BISWAS, B. 1982. Studies on morphometry of Punius chola (Ham-Buch, 1882) (Cypriniformes: Cyprinidae). Univ. J. Zool., Rajshahi Univ.1: 29-34.

CARLANDAR, K.D. and SMITH, L.L.JR. 1945. Some factors to consider in the choice between 
standard, fork or total length in fishery investigations. Copeia 1: 7-12.

CHONDAR, S.L. 1977. Morphometric characters and their relationship in Gudusia chapra (Ham.)Proc. Ind. Acad. Sec. B 80:57-67.

CORTI, M. and CROSETTI, D. 1996. Geographic variation in the grey mullet: a geometric morphometric analysis using partial warp scores. J. Fish Biol. 48(2): 255-269.

DARS, B.A., NAREJO, N.T. and AWAN, K.P. 2012. Morphometric, meristic characters and their relationships in Channa punctatus from River Indus near Jamshoro Sindh, Pakistan. Sindh Univ. Res. J. (Science Series) 44(1):91-96.

DASGUPTA, M. 1991. Biology of the mahseer, Tor putitora (Hamilton) collected from Garohills, Meghalaya. Indian. J. Fish. 38 (2): 129-131.

DAY, F.1889. The Fauna of British India, including Ceylon and Burma: Fishes, Vols. I and II: Today and Tomorrows Printers and Publishers, New Delhi, pp. 509-548.

FATIMA, M. 1991. Studies on the biology of a grey mullet, Rhinomugil corsula (Hamilton), collected from River Yamuna. PhD thesis, Department of Zoology, Aligarh Muslim University, Aligarh, India, pp. 198.

FROESE, R. and PAULY, D. 2018. FishBase. World Wide Web Electronic Publication. http://www.fishbase.org/

GODSIL, H.C. 1948. A preliminary population study of the yellow fin tuna and albacore. Calif. Fish and Game 70: 90.

HILE, R. 1948. Standardization of method of expressing length and weight of fish. Trans. Am. Fish. Soc.75: $157-164$.

HOLDEN, M.J. and RAITT, D.F.S. 1974. Manual of fisheries science Part-II. Methods of resource investigation and their application. FAO fisheries technical paper 115, pp. 214.

HOQUE, B. 1984. Morphometric characters and their relationship in Bombay duck, Harpodon neherius (Ham.). Bangladesh J. Zool. 12(2):105-108.

HOQUE, B. and RAHMAN, K.M. 1985. Morphometric characters and their relationship in Gudusia chapra (Ham.) Chittagong Univ. Stud. Part II. Science 9(2):85-88.

HOSSAIN, S.M., SHARIFUZZAMAN, S.M. and CHOWDHURY, S.R. 2016. Environmental impact of ship recycling industry in Bangladesh (Work package 1, Study Component 2) WBS Element No. TC/1514-01-2320. In Watkinson, R. V. 2016. (ed.) Safe and environmentally sound ship recycling in Bangladesh - Phase I, Programme No. TC/1514, Final report, INTERNATIONAL MARITIME ORGANIZATION, Roy Watkinson Environmental Consulting Ltd., Sussex, UK, pp.112.

IBANEZ-AGUIRRE, A.L., CABRAL-SOLIS, E., GALLARDO-CABELLO, M. and ESPINO-BARR, E. 2006. Comparative morphometrics of two population of Mugil curema in the Atlantic and Pacific coasts. Scientia Marina 70(1): 139-145.

ISMEN, A. 2001. Use of a discriminant function for the morphometric and meristic separation of Whiting Stocks, Merlangius merlangus euxinus, along the Turkish Black Sea Coast. Turkish J. 
Zool. 25: 297-304.

JAISWAR, A.K., PARIDA, P.K., CHAKRABORTY, S.K. and PALANISWAMY, R. 2004. Morphometry and length-weight relationship of obtuse barracuda, Sphyraena obtusata, from the Bombay waters, west coast of India. Int. J. Mar. Sci. 33(3): 307-309.

JAYARAM, K.C. 1981. The freshwater fishes of India, Pakistan, Bangladesh, Burma, Sri Lanka: a handbook, Zoological Survey of India (Calcutta), pp. 475.

JOHAL, M.S., CHAHAL, J.S., and JOIR, R.B. 1989. On the morphometry of Colisa fasciata from Panjab, India. (Perciformes: Anabantidae).Vest. Cs. Spolec. Zool. 53:188-194.

KAUR, V., ANA, Y. and HEER, B.K. 2019. Morphometric analysis of Labeo rohita (Hamilton) from pond near Kalayat, Kaithal, Haryana, India. Int. J. Fish. Aquat. Stud. 7(3): 299-306.

KOHESTAN-ESKANDARI, S., ANVARIFAR, H. and MOUSAVI-SABET H. 2006. Detection of morphometric differentiation of Liza aurata (Pisces: Mugilidae) in Southeastern of the Caspian Sea, Iran. Our Nature 11(2): 126-137.

LAGLER, K.F. 1956.Freshwater Fishery Biology. $2^{\text {nd }}$ edition. W.C. Brown Company, Dubuque, Iowa, pp. 403.

MARR, A.C. 1955. The use of morphometric data in systematics and relative growth studies in fishes. Copeia1: 23-31.

MATHER, K. 1964. Statistical Analysis in Biology (5 $5^{\text {thed. }}$.). Methuen, London.

MOTOMURA, H., PAULIN, C.D. and STEWART, A.L. 2005. First records of Scorpaena sonaria (Scorpaeniformes: Scorpanidae) from the Southwestern Pacific Ocean and comparison with the Northern Hemisphere population. New Zealand J. Mar. and Fresh. Res.39: 865-880.

NACUA, S.S., DORADO, E.L., TORRES, M.A.J. and DEMAYO, C.G. 2010. Body shape variation between two populations of the white Gobi, Glossogobius giuris (Hamilton and Buchanan). Res. J. Fish. Hydrobiol. 5: 44-51.

NAREJO, N.T. 2010. Morphometric characters and their relationship in Gudusia chapra (Hamilton) from Keenjhar lake (Distt: Thatta), Sindh. Pakistan J. Zool. 42(1): 101-104.

NATH, R.P. and KUNDU, J.K. 2017. Morphometric analysis: A tool to identify green puffer fish Tetraodoan fluviatilis (Hamilton, 1822) from Digha coastal region, West Bengal, East coast of India. International J. Zool. Stud. 2(5): 203-211.

NAYMAN, N. 1965. Growth and Ecology of fish population. J. Anim. Ecol. 20: 201-219.

PILLAI, M.P.K. 1983. On the biometry, food and feeding and spawning habits of Otolithes ruber (Schneider) from Porto-Novo. Indian J. Fish. 211(1): 69-73.

PILLAY, T.V.R. 1954. The biology of the grey mullet, Mugil tade, Forskal, with notes on its fishery in Bengal. Proc. Nat. Inst. Sci. India. 20: 187-217.

PILLAY, T.V.R. 1957. A morphometric study of the population of Hilsha ilisha (Ham.) of the River Hoogly and of the Chikla Lake, India. IBID. 4: 244-386.

PRAKASH, M. and VERMA, B.R. 1982. Morphometric characters and their relationship in Notopterus 
notopterus (Pallus). Bangladesh J. Zool. 10(1): 14-21.

QUIST, M.C., BOWER, M.R., HUBERT, W.A., PARCHMAN, T.L., and MCDONALD, D.B. 2009. Morphometric and meristic differences among blue head suckers, flannel mouth suckers, white suckers, and their hybrids: Tools for the management of native species in the Upper Colorado River Basin. North American Journal of Fish. Manag. 29:460-467.

RANGANATHAN, V. and NATARAJAN, V. 1969. Studies on the occurrence and biology of Rhinomugil corsula in Krishnagiri and Sathanur Reservoirs Tamil Nadu, India. J Bomby. Nat. Hist. Soc. 66: 519-532.

RAZZAQ, W., IQBAL, F., ZUBIA, M. and MASOOMA, K. 2015. Study of some morphometric and merestic characters of a Parassi mullet, Mullet incilis (Mugilidae: Mugiliformes) from the Indus River at Sukker district of Province Sindh, Pakistan. Biol. For. An Int. J. 7(1): 767-772.

RENJINI, P.K. and NANDAN, B.S. 2011. Length-weight relationship, condition factor and morphometry of gold spot mullet Liza parsia (Hamilton, 1822) from Cochin estuary. Indian J. Geo-marine Sci. 40(4): 567-571.

RIEDE, K. 2004. Global register of migratory species from global to regional scales. Final Report of the R\&D Project 80805 081. Federal Agency for Nature Conservation, Bonn, Germany. pp. 329.

ROYCE, W.F. 1963. A morphometric study of yellow fin tuna, Thunnus albaeore (Bonnaterr). U.S. fish and wildlife service, Fishery Bull. 63: 395-443.

SAROJINI, K.K. 1958. Biology and fisheries of the grey mullets of Bengal: ii. Biology of Mugil cunnesius Valencinnes. Indian J. Fish. 5(1): 56-76.

SULTANA, S., SHAH, M.S., ISLAM, S.S. and GHOS, A.K. 2013.Taxonomy and other biological aspect of Rhinomugil corsula (Hamilton). Int. J. Res. Biol. Sci. 3(3):123-131.

TALWAR, P.K. and JHINGRAN, A.G.1991. Inland fishes of India and adjacent countries. Vol-1 and Vol2. Oxford and IBH publishing Co. Pvt. Ltd. New Delhi, Bombay and Calcutta, pp. 1063.

TANDON, K.K., JOHAL, M.S. and BALA, S. 1993. Morphometry of Cirrhinus reba (Hamilton) from Kanjli wetland, Panjab, India. Res. Bul. Panjab. Univ. 43(i-iv): 117-128.

TUDELA, S. 1999. Morphological variability in a Mediterranean, genetically homogeneous population of the European Anchovy, Engraulis encrasicolus. Fish. Res. 42: 229- 243.

TURAN, C. 2004. Stock identification of Mediterranean horse mackerel (Trachurus mediterraneus) using morphometric and meristic characters. ICES J. Mar. Sci. 61: 774-781.

TURAN, C., ERGUDEN, D. GURLEK, M., BASUSTA, N. and TURAN, F. 2004. Morphometric structuring of the anchovy (Engraulisen crasicolus L.) in the Black, Aegean and northeastern Mediterranean Seas. Turk. J. Vet. Anim. Sci. 28: 865-871.

VISHALAKSHI, C. and SINGH, B.N. 2008. Differences in morphological traits between two sibling species, Drosophila ananassae and D. pallidosa. Zool. Stud. 47: 352-359.

WITTHAMES, P.R., GREER, M., WALTER, M., DINIS, T. and WHITTING, C.L. 1995. The geographical 
variation in the potential annual fecundity of Dover sole, Solea solea, from European Shelf Waters during 1991. Neth. J. Sea. Res. 34: 45-48.

ZUBIA, M., REHANA, Y., KATSELIS, G., OMER, M.T., LAKHT-E-ZEHRA, YEAMIN M.H. and SAMEE, H.M. 2015. Comparative survey of morphometric and meristic studies of four mullet species of family Mugilidae from Pakistan in relation to total body length. Indian J. geo-marine sci. 44(4): 562-572.

(Manuscript received on 3 March, 2021 revised on 10 June, 2021) 